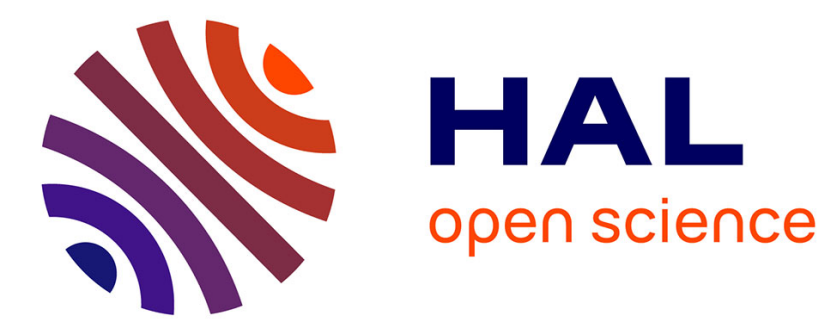

\title{
EFFECTS OF ANTI-TOBACCO BRANDS AD PARODIES ON CIGARETTE BRANDS ATTITUDE
}

Béatrice Parguel, Renaud Lunardo, Jean-Charles Chebat

\section{To cite this version:}

Béatrice Parguel, Renaud Lunardo, Jean-Charles Chebat. EFFECTS OF ANTI-TOBACCO BRANDS AD PARODIES ON CIGARETTE BRANDS ATTITUDE. AMS, May 2012, United States. halshs-00703906

\section{HAL Id: halshs-00703906 \\ https://shs.hal.science/halshs-00703906}

Submitted on 4 Jun 2012

HAL is a multi-disciplinary open access archive for the deposit and dissemination of scientific research documents, whether they are published or not. The documents may come from teaching and research institutions in France or abroad, or from public or private research centers.
L'archive ouverte pluridisciplinaire HAL, est destinée au dépôt et à la diffusion de documents scientifiques de niveau recherche, publiés ou non, émanant des établissements d'enseignement et de recherche français ou étrangers, des laboratoires publics ou privés. 


\title{
EFFECTS OF ANTI-TOBACCO BRANDS AD PARODIES ON CIGARETTE BRANDS ATTITUDE
}

\author{
Béatrice Parguel, CNRS, DRM, UMR 7088, Université Paris Dauphine \\ Renaud Lunardo, Bordeaux Ecole de Management, France \\ Jean-Charles Chebat, HEC Montreal, France
}

\begin{abstract}
This paper compares the effects of anti-tobacco ad parodies and visual cigarette package warnings on emotional and cognitive responses of young adults. The findings indicate that graphic-only ad parodies can compete with warnings in their attempt to damage consumers' attitude toward tobacco brands through the health beliefs they lead consumers to associate to the brand. On the contrary, text-only ad parodies prove counterproductive and lead to a boomerang effect characterized by an increase in consumers' tobacco brand attitude.
\end{abstract}

\section{INTRODUCTION}

Cigarette consumption is a major cause of premature death, killing nearly 6 million people each year (World Health Organization 20111). In particular, young adulthood is a period of continued smoking progression when smokers establish regular and long-term smoking practices (Hammond 2011). As a result, many government agencies are taking initiatives to keep young adults away from cigarette consumption.

In the same attempt to reduce the number of smokers, anti-tobacco nonprofit groups use creative alternative methods of communication to voice their message, by creating ad parodies they spread though web-sites (Vanden Bergh et al. 2011). Spoofing advertising allows activists sharing entertainment, attacking brands and showing off personal skills (Vanden Bergh et al. 2011). However, studies mainly focused on consumer-created ad parodies undertaken by brand loyalists on behalf of the brand and left anti-brand ad parodies effects on persuasion largely unexplored (Berthon, Pitt and Campbell 2008). Clearly, research is lacking on whether anti-brand ad parodies could be a means of influencing the attitudes, perceptions and resulting behaviors. In the case of tobacco, it is now important for both anti-brand activists who create and spread anti-tobacco brand ad parodies, and the researchers who study them, to gain a better understanding of their relative efficiency compared to more classical anti-tobacco warnings, such as cigarette package warnings.

We thus focus in this paper on anti-tobacco brand ad parodies to study whether they can really impact consumer's attitude toward tobacco brands, and, if so, the mechanisms by which such an effect occurs. Such a focus on cigarette brands attitude as the dependent variable appears highly relevant since cigarette brands attitude has largely been shown to influence tobacco consumption behaviors as a means of self-expression and peers acceptance among young adults (Pechmann and Ratneshwar 1994; Pechmann and Knight 2002). Also, focusing on consumers' attitude toward specific cigarette brands and not toward smoking in general finds support in that anti-tobacco warnings appear relatively ineffective in influencing attitude toward smoking among young adults who already hold strong preconceptions on smoking's adverse health effects (Pechmann and Ratneshwar 1994). However, they can clearly influence a more changing variable such as cigarette brands attitude (Germain et al. 2009). Thus, we focus more precisely on the following questions: What is the influence of anti-tobacco brand ad parodies compared with cigarette package warnings on consumers' attitude about cigarette brands? Do the effects of antitobacco brand ad parodies that parody only the ad text differ from those that parody both the ad text and graphics?

\section{ANTI-BRAND AD APRODIES: AN OVERVIEW}

Two main criterions are likely to discriminate between ad parodies: valence (i.e., positive, neutral or negative) and source (i.e., the brand itself, its competitors, brands in other categories, ordinary individuals wishing to express their personal creativity or activists, including unsatisfied customers and employees). Within this typology, anti-brand ad parodies belong to the kind of negatively valenced parodies designed by activists to warn consumers against brands. They range from poking harmless fun to malicious and spiteful jibes directed at some of the world's best known brands (Hollenbeck and Zinkhan 2006).

\footnotetext{
${ }^{1}$ http://www.who.int/mediacentre/factsheets/fs339/en/index.html
} 
From a practical point of view, ad parodies refer to hijack actions on official brand ads, mixing part of those official ads' materials ( logo, slogan, picture, style) with new ones in a sarcastic way to make the original ad ridiculous or distasteful. Ad parodies display different levels depending on the materials that they parody. In this paper, we distinguish between "text-only ad parodies", only parodying the official ad text, and "graphic-only ad parodies", only parodying the official graphics. While ad parodies were previously the prerogatives of professionals, today, anyone with a computer, a sense of inventiveness and a statement to make can craft a professional looking ad parody, strongly resembling in form to the ad of the brand to be criticized (Berthon et al. 2008; Vanden Bergh et al. 2011).

Besides, the Internet has empowered ordinary consumers and nonprofit groups by providing powerful means to express their views effectively and tools to reach a large targeted audience at will. Easier to make thanks to inexpensive media software, ad parodies are then as well easier to spread through the Internet and its vehicles (e.g., YouTube, Facebook, DailyMotion). Therefore, anti-brand ad parodies are becoming increasingly common on line, especially for cigarette brands, which appear among the most spoofed brands worldwide along with alcohol, computer and clothing brands. As an illustration, anti-brand activists have for instance launched Adbusters, a website (http://www.adbusters.org) on which appears Joe Chemo, the Joe Camel mascot, suffering from lung cancer in his retirement years.

Spoofing cigarette brands ads on line, activists question cigarette brands advertising impact and legitimacy. In the long term, their objective is to counter the effects of official cigarette brands advertising, to warn people against their hazards and to affect individual cigarette consumption. To do so, they target specific brands, such as Marlboro or Camel, because they symbolize the tobacco industry. Still, we do not know much on their precise effects in the short term on cigarette brands attitude. Vanden Bergh et al. (2011) suggest the brand may be harmed if the denunciation effect predominates and the original brand is its target. However, if the humorous effect predominates, humor might reinforce pleasant emotional associations with the brand, preventing it form being harmed. Alternatively, one would expect that the brand may not be harmed if people understand that the parody's purpose is to use the brand's meanings to attack something more general and not the targeted brand in particular. Our goal is thus to ensure that activists are right in targeting specific brands through humoristic ad parodies to warn people against hazards of smoking and to damage consumer's attitude toward the brand. The question remains how - that is through what specific route - ad parodies exert their persuasive effects.

\section{CONCEPTUAL BACKGROUND: PERSUASION OF ANTI-TOBACCO WARNINGS}

Persuasion refers to any instance in which an active attempt is made to change a person's mind (Petty and Cacioppo 1981, 6). Advertising researchers have long been studying attitude change because it is presumed to direct behaviors (Petty and Cacioppo 1981, 7). Focusing on brand attitude, they clearly recognize the influence of consumers' emotional and cognitive reactions to advertising (Mitchell and Olson 1981; MacKenzie, Lutz and Belch 1986). These two routes are here used to explain cigarette brands attitude and compare anti-tobacco brand ad parodies and cigarette package warnings relative efficiency in persuading young adults.

\section{The emotional route to persuasion}

As kinds of anti-tobacco warnings, anti-tobacco brand ad parodies and cigarette package warnings are both likely to induce negative emotional reactions, such as fear or disgust (Goodall and Appiah 2008). However, the extent to which ad parodies and cigarette package warnings elicit negative emotional responses may differ. Comparing central versus peripheral elements way of influence, the elaboration likelihood model (Petty and Cacioppo 1981) suggests that peripheral elements, such as execution elements or the characteristics of the source, have their main influence through the emotional route. On the contrary, central elements, including texts, have their main influence through the cognitive route.

Thus, the influence of ad parodies on negative emotional reactions might more depend on the image they parody than on the text they parody. As text-only parodies display the positive official ad graphics, when graphic-only ad parodies display new striking materials, we expect graphic-only ad parodies to elicit more negative emotional reactions than text-only ad parodies. Besides, as cigarette package warnings often feature particularly shocking pictures while graphic-only ad parodies take their inspiration in official ads materials and advertising conventions and therefore depict the dangers of tobacco use in a less concrete manner, we predict that cigarette package warnings will elicit more negative emotional reactions than graphic-only ad parodies. Hence we posit the following:

H1: Graphic-only ad parodies elicit more negative emotional reactions than text-only ad parodies (a) but less than cigarette package warnings (b). 
At the same time, anti-tobacco brand ad parodies are consumer-created ad parodies designed to make laugh, even when they are created to have specific effects on a targeted audience and not just for fun (Vanden Bergh et al. 2011). An observation of the comments left on YouTube regarding anti-tobacco brand spoof videos highlight that they do make laugh. On YouTube, the main emotional reactions induced by anti-tobacco brand ad parodies are upbeat feelings, far ahead of negative emotional reactions. Therefore, ad parodies are likely to elicit more positive emotional reactions compared with cigarette package warnings.

Besides, the literature has pointed out that a caricature has to create a gap (i.e., there should be a disparity between the image and the realty of the object of caricature) to work and make laugh in the field of politics (Speck 1991). Humor is thus experienced when a discrepancy is experienced and finally solved when the subject understands the origin of the incongruity and feels release. Applying these proposals to ad parodies, Vanden Bergh et al. (2011) suggest that an ad parody surprises the viewer when it creates confusion by incorporating elements that do not fit with his expectations. Then, the viewer understands that the parody is indicating how the original ad might not have been telling the whole truth and experiences positive emotions such as release and humor.

Considering spoof advertising, text-only ad parodies display a strong discrepancy, mixing graphic elements favorable to cigarette brands and familiar to the viewer with an unfavorable text. On the contrary, there is no such gap in graphic-only ad parodies, where all elements display a convergent message. Therefore, as text-only ad parodies create a bigger incongruity than graphic-only ad parodies, they might elicit more positive emotional reactions. Thus, we propose the following:

H2: Graphic-only ad parodies elicit less positive emotional reactions than text-only ad parodies (a), but more than cigarette package warnings (b).

\section{The cognitive route to persuasion}

The cognitive route represents the product of a consumers' elaboration of the information presented in a persuasive message. Elaboration means that the receiver takes the arguments of the brand and integrates them into his or her own attitude. As a component of brand image, the role of brand associations is crucial in the process of elaboration. In this paper, we focus on the two strongest cigarette brands associations, namely their perceived risk and their symbolic image.

Regarding perceived risk, studies on graphic tobacco warnings conclude that visual labels are more visible and easier to understand (Gallopel-Morvan et al. 2011), leading to more efficacy in communicating smoking health hazards (Hammond 2011). The same reasoning should play to compare text-only ad parodies with graphic-only ad parodies. Besides, the former communicate smoking health hazards in an ambivalent way as it contains non-convergent elements when the latter depict them in a clearer way with two convergent elements. Therefore, the risks associated with cigarette brands are easier to understand in graphic-only ad parodies compared with text-only ad parodies.

When comparing the relative influence of graphic-only ad parodies versus cigarette package warnings on risks perception, we may observe that cigarette packages are poorly branded. They only exhibit cigarette brands name and warnings, and could be perceived as boring and unattractive, making therefore health warning more noticeable (Germain, Wakefield and Durkin 2009) compared with the richer message developed by graphic-only ad parodies. Relying on previous arguments, we propose the following hypotheses:

H3: Subjects exposed to graphic-only ad parodies perceive cigarette brands as more risky than subjects exposed to text-only ad parodies (a), but less risky than subjects exposed to cigarette package warnings (b).

Cigarette brands official ads are crafted to address young adults' need for independence, self reliance, and freedom (Pechmann and Ratneshwar 1994). They also aim at promoting peer acceptance among targeted young people and positive lifestyle images to enhance smoking social acceptability and enhance cigarette brands symbolic beliefs.

As noted by Vanden Bergh et al. (2011), when creating ad parodies, consumers create a viral object that might help in spreading the original ad's themes and imagery. Anti-tobacco activists might thus potentially reactivate cigarette brands positive symbolic beliefs in consumers' mind and obtain the same results as official ads. They also might enhance social benefits associated to smoking that, those having been found by researchers relying on theories like the Social Learning Theory (Bandura 1977; Aloise-Young et al. 1994) or the Stereotype Priming Theory (Maheswaran1994; Pechmann and Knight 2002) to be very efficient to influence young. If anti-tobacco brand ad parodies present smokers as physically attractive, engaged in exciting activities, then they could run counter to messages that smoking is dangerous to one's health and reinforce perceptions that smoking is a normative consumption product (Devlin et al. 2007). As text-only ad parodies appropriate the graphic elements of official ads, they are more likely to enhance brands positive symbolic beliefs compared with other forms of anti-tobacco warnings. 
Besides, ad parodies may create a "Doppelgänger Brand Image", a set of disparaging images about a brand that are able over time to coalesce into a coherent set of opposing meanings that plague brand (Thompson, Rindfleisch and Arsel 2006). This is especially true for graphic-only ad parodies which associate brands with new negative graphical conventions. As graphiconly ad parodies crash brands previous meanings, they are less likely to enhance brands positive symbolic beliefs compared with cigarette package warnings. Thus, we posit:

H4: Subjects exposed to graphic-only ad parodies associate less positive symbolic beliefs to cigarette brands than subjects exposed to text-only ad parodies (a) and cigarette package warnings (b).

\section{The change in cigarette brands attitude}

On the emotional route, negative emotions experienced by the individual exposed to cigarette warnings result in an increase in the persuasiveness of these warnings (Rogers 1985). Fear appeals have been shown to have the most impact on behaviors such as quitting (Tanner et al. 1991; Hammond 2011). Besides, negative emotions are supposed to transfer to the object to which they are associated by mere association (Mitchell and Olson 1981). Following the same argument, anti-tobacco brand ad parodies that generate upbeat feelings might enhance cigarette brands attitude.

The cognitive route provides an alternative explanation for the process of change in cigarette brands attitude. First, the Protection Motivation Model (Rogers 1975) and the Health Belief Model (Rosenstock 1974) posit that consumers' persuasion depends on the appraisal of the severity of the risks. In the end, this perception of the risks associated with cigarette brands consumption is likely to lead to brand avoidance. Second, the positive symbolic meanings associated with cigarette brands are likely to transfer to cigarette brands attitude (Pechmann and Ratneshwar 1994; Pechmann and Knight 2002). Our last hypothesis will test these conjectures and compare the mechanisms by which graphic-only and text-only ad parodies, as well as cigarette package warnings, can lead to changes in consumer's attitude toward the tobacco brand. We expect that the effect of anti-tobacco warnings (representing both ad parodies and cigarette package warnings) on attitude toward the brand is mediated by the emotional reactions experienced by the subjects, and by their brand beliefs. Specifically:

H5: The effects of anti-tobacco warnings (representing both ad parodies and cigarette package warnings) on attitude toward the brand are mediated by emotional and cognitive reactions. Graphic-only ad parodies will lead to lower attitude toward the brand because of their positive effect on negative emotions (fear and disgust) (H5a and H5b) and health beliefs (H5c). On the contrary, text-only ad parodies will lead to higher attitude toward the brand because of their effect on positive emotions (upbeat feelings) (H5d) and on symbolic beliefs (H5e).

\section{METHOD}

\section{Research design, stimulus selection and sample}

To test our predictions, we carried an experiment considering 3 different kinds of anti-tobacco warnings: a text-only ad parody, a graphic-only ad parody and a cigarette package warning. The text-only and graphic-only ad parodies, as well as the cigarette package warning used for the experiment were all real materials in order to increase the realism of the study.

To ensure that respondents were familiar with the brand and thus to control also for familiarity, Marlboro, a top selling brand in the United States and Europe (Hemdev 2005) was chosen as the brand in the experiment. The text-only ad parody which has been chosen was the Marlboro picture presenting two cowboys riding into the sunset. The only single change from the original ad which had been made by the ad parody developers resulted from the humoristic text warning "I miss my lung Bob". The graphic-only ad parody used the original sentence "Welcome to Marlboro Country", the graphic change made by the ad parody developers had consisted in depicting a graveyard in the background. Since pictorial warnings have been found to be the most persuasive (Hammond 2011), the cigarette package warning condition included a graphic-only warning. Precisely, the pack provided a warning showing one healthy lung and one damaged, and a verbal warning "Smoking causes fatal lung cancer".

As the goal of the research was to study the effects of ad parodies on young adults, participants were 139 university students (mean age $=22,35 \%$ being men and $65 \%$ being women, $43 \%$ being smokers). The respondents were randomly assigned to one of the three experimental conditions. Chi-Square tests and a t-test revealed that respondents in the three experimental conditions were similar in terms of gender $\left(\chi^{2}\right.$ Gender $\left.=.868, d f=2, p>.05\right)$ and tobacco consumption habits $\left(\chi^{2}\right.$ smoker $=1.345, d f$ $=2, p>.05)$. 


\section{Measures}

Outcome variables included upbeat feelings, fear and disgust evoked by the ad parody and the cigarette package warning, health and symbolic beliefs associated to the brand, and attitude toward the brand. All the scales were either entirely or partially adopted from previous research. Note that to keep the questionnaire short without compromising the quality of the measure (Bergkvist and Rossiter 2007), attitude toward the brand was measured through a single-item measure asking respondents "the extent to which they liked the Marlboro Brand". A description of the scale and of their psychometric properties including reliability coefficients are presented in Table 1. Each item was rated on a 7-point scale ranging from 1 (Not at all) to 7 (Very Strongly). We also measured participants' smoking status as a potential covariate. Participants had to rate the extent to which they were "non-smokers" or "heavy smokers". People answering "non-smokers" were labeled nonsmokers, the other were labeled "smokers".

\section{RESULTS}

The effects of ad parodies versus cigarette package warning exposure on emotional and cognitive responses were examined using analyses of variance (ANOVA). Independent samples t-tests were also used to test the differences between graphiconly ad parodies and respectively text-only ad parodies and cigarette package warnings (Table 2).

\section{Effects of ad parodies exposure on emotional responses}

Findings indicate that the ad parodies versus cigarette package warning exposure manipulation had a significant effect on fear $(\mathrm{F}(4,136)=7.54 ; p<.05)$. Results from t-tests show that graphic-only ad parody exposure condition resulted in a significant increase in fear only when compared with text-only ad parody exposure condition $\left(\mathrm{M}_{\text {Graphic }}=4.06 \mathrm{vs} . \mathrm{M}_{\mathrm{Text}}=2.72, p<.001\right)$. No significant difference between graphic-only ad parody exposure condition and cigarette package warning exposure condition was found $\left(\mathrm{M}_{\text {Warning }}=3.80, p>.05\right)$. Results dealing with disgust offer the same pattern of results. However, the results differ in that the highest level of disgust is obtained in the cigarette package warning condition $\left(\mathrm{M}_{\mathrm{Warning}}=4.84\right)$. Disgust in the graphic-only ad parody exposure condition is significantly higher than the ones obtained in the text-only ad parody exposure condition $\left(\mathrm{M}_{\text {Graphic }}=4.06 \mathrm{vs}\right.$. $\left.\mathrm{M}_{\mathrm{Text}}=2.75, p<.001\right)$ but lower than in the cigarette package warning exposure condition $\left(\mathrm{M}_{\mathrm{Warning}}=4.84, p<.05\right)$. These results offer support for H1(a) and partial support for H1(b).

Regarding positive emotions, our findings indicate that the ad parodies versus cigarette package warning exposure manipulation had a significant effect on upbeat feelings $(\mathrm{F}(2,136)=6.62 ; p<.01)$. Specifically, graphic-only ad parody exposure condition resulted in a significant decrease in upbeat feelings when compared with text-only ad parody exposure condition $\left(\mathrm{M}_{\text {Graphic }}=1.46\right.$ vs. $\left.\mathrm{M}_{\text {Text }}=2.25, p<.01\right)$. However, the graphic-only ad parody exposure did not induce more upbeat feelings that the cigarette package warning exposure $\left(\mathrm{M}_{\text {Warning }}=1.55, p>.05\right)$. Thus, $\mathrm{H} 2(\mathrm{a})$ is supported but not $\mathrm{H} 2$ (b).

\section{Effects of ad parodies exposure on cognitive responses}

Results indicate that the ad parodies and warning exposure manipulation has a marginally significant effect on health beliefs $(\mathrm{F}(2,136)=2.65 ; p<.10)$, and a much highly significant effect on symbolic beliefs associated to the brand $(\mathrm{F}(2,136)=$ 4.99; $p<.01)$. Regarding health beliefs, the graphic-only ad parody exposure condition led to the highest mean of health beliefs $(M=5.49)$. More precisely, t-tests revealed a marginally significant between graphic-only and text-only ad parodies exposure conditions difference $\left(\mathrm{M}_{\text {Graphic }}=5.49\right.$ vs. $\left.\mathrm{M}_{\mathrm{Text}}=4.96, p<.10\right)$, and a more significant difference when comparing the effect of graphic-only ad parody to the one of cigarette package warning $\left(\mathrm{M}_{\mathrm{Graphic}}=5.49\right.$ vs. $\left.\mathrm{M}_{\text {Warning }}=4.79, p<.05\right)$. Thus, these results offer support for $\mathrm{H} 3(\mathrm{a})$, but not for $\mathrm{H} 3(\mathrm{~b})$.

Results regarding the effects of ad parodies and warnings on symbolic beliefs are clearer. They reveal that being exposed to text-only ad parodies significantly leads to the highest level of symbolic beliefs $\left(\mathrm{M}_{\text {Text }}=3.64\right)$. This level is significantly higher than the one of individuals exposed to graphic-only ad parodies $\left(\mathrm{M}_{\text {Text }}=3.64\right.$ vs. $\left.\mathrm{M}_{\text {Graphic }}=2.82, p<.05\right)$. Symbolic beliefs induced by exposure to graphic-only ad parodies did not differ to the ones elicited by exposure to cigarette package warnings $\left(\mathrm{M}_{\text {Graphic }}=2.82\right.$ vs. $\left.\mathrm{M}_{\text {Warning }}=2.72, p>.05\right)$. These results offer support for H4(a) but not H4(b).

\section{Tests of the Mediating Roles of Emotions and Cognitions}


A primary goal of this study was to examine a potential underlying mechanism that might account for the ad parodies exposure effects on attitude toward the brand. Thus, we tested emotions and cognitions as potential mediators of these effects. Following Zhao, Lynch and Chen's (2010) procedure, we used Preacher and Hayes' (2008) macro and 5000 bootstrapped samples to determine whether the indirect effect was significant.

We decided to study the mechanism explaining the effects of ad parodies exposure on attitude toward the brand by comparing the effects of graphic-only ad parodies to respectively the ones of text-only ad parodies, and then the ones of cigarette package warnings. For each mediation analysis, the graphic-only ad parody condition was coded 1, so that a positive effect of the independent variable on the mediator in the indirect path can be interpreted as the effect of the graphic-only ad parody exposure and a negative effect as the one caused by the other kind of warning. Furthermore, smoking status was included in the analyses as a control variable. Since gender, age and education were not significantly different from one group to one another, no other individual variable was included as a control variable.

First, when comparing the mechanism by which being exposed to graphic-only ad parodies versus text-only ad parodies lead to changes in attitude toward the tobacco brand, the most striking result lies in the absence of mediating effects of any emotions. Indeed, all indirect effects of fear, disgust and upbeat feelings are not significant with 95 confidence intervals including zero, providing no support to H5 (a), H5(b) and H5 (c). On the contrary, results highlight that the only mediating variables is symbolic beliefs ( $a \times b=-.12$, the confidence interval excluding 0 ). The negative sign of the mediating effect reveals that increases in Ab may be due to increases in symbolic beliefs induced by text-only ad parodies. This result thus supports H5 (e). No mediating effect of health beliefs was found out. Smoking status was not significant as a covariate $(p>$. 10). These results bring to the light the importance of symbolic beliefs in the influence of anti-tobacco ad parodies and their ability to lead consumers to develop better attitudes toward the tobacco brand, the exact opposite effect assigned to such textonly ad parodies.

Second, when comparing the mechanism underlying the effects of being exposed to graphic-only ad parodies versus cigarette package warnings, the only indirect effect that is significant is the one of health beliefs $(a \times b=-.18$, the confidence interval excluding 0). Thus, here again, emotions do not play any mediating role in the influence of ad parodies versus warnings exposure on attitude, leaving the influence of ad parodies and warnings on attitude to be explained by cognitions. Since graphic-only ad parodies exposure condition was coded 1, the negative sign of the mediating effect reveals that increases in $\mathrm{Ab}$ may be due to health beliefs induced by the graphic-only ad parodies exposure. This result supports H5 (b). As for the analysis of emotions as mediators, smoking status here was not significant as a covariate $(p>.10)$.

\section{GENERAL DISCUSSION}

This research aimed at demonstrating that ad parodies may be an original and creative new way to take part in the public fight against smoking behavior by leading young adults to develop negative attitudes toward tobacco brands. Overall, our study contributes to a better understanding of the effects of ad parodies in the three following ways. First, we introduce a distinction between text-only and graphic-only ad parodies, whereas most studies focus on parody without proposing any distinction between the different kinds of parodies (Rumbo 2002; Vanden Bergh et al. 2011). This distinction allows refining the process through which ad parodies may or may not reach the goal of damaging consumers' attitude toward tobacco brands. Second, we oppose ad parodies to anti-tobacco warnings to compare their efficiency in leading to negative emotions, such as fear, or negative beliefs, such as health beliefs. Third, we explain the mechanism under which both text-only and graphic-only ad parodies influence consumer's attitude toward tobacco brands.

Regarding this third objective, results show that what mediates the comparative effects of ad parodies and warnings are not emotions but cognitions. Second, results show that graphic-only ad parodies can compete with warnings in their attempt to damage consumers' attitude toward tobacco brands through the health beliefs they lead consumers to associate to the brand, which decreases attitude toward the brand. Furthermore and of much importance, due to the symbolic beliefs they induce, text-only ad parodies may prove counterproductive and lead to a boomerang effect characterized by an increase in consumers' tobacco brand attitude.

\section{Practical implications for public policy and activists}


The preceding findings offer potentially important implications. for both public health policy and activists or organizations who aim at disparaging smoking behavior. These implications stem from the direct and mediating effects that we found in the study. Although many antismoking campaigns have focused primarily on emotional-based reasons not to smoke, especially through a focus on fear (Laroche et al. 2001), our main result relates to the mediating role of health beliefs. This result suggests that cognitive approaches may also be of interest to study the beneficial effects of warnings labels. Contrary to warnings, graphic-only ad parodies are more likely to hurt tobacco brands' image through the negative health-related associations that consumers draw. This result reveals for public policy officers that by directly showing how through graphic ad parodies the hazards related to tobacco consumption, they can lead consumers to develop negative attitude toward tobacco brands.

For activists who create ad parodies to hurt tobacco brands, graphic-only ad parodies may represent creative ways of decreasing such attitude indirectly through health beliefs. Meanwhile, our results also suggest avoiding text-only spoof ads prime symbolic beliefs which in turn positively affect consumers' attitude toward the tobacco brand, the exact opposite reaction of the one that ad parodies developers aim at generating.

\section{Limitations and further research}

Future studies should attempt to uncover whether the change in attitude toward the tobacco brands is an actual reflection of intention to quit and quitting behavior. Because attitude toward the brand has been shown to mediate the effect of warnings of intentions to quit (Sabbane, Bellavance, and Chebat 2009), graphic-only warning that damage the attitude toward the brand may lead to less intention to smoke. However, nicotine is very addictive (Andrews et al. 2004; Kees et al. 2010) and we recognize that that it may be difficult to really distinguish between the effect of ad-parodies (text-only and graphic-only ad parodies versus warning exposure) and the effect of addiction. 


\section{TABLES}

Table 1: Description, descriptive statistics and psychometric properties of the multi-items scales

\begin{tabular}{|c|c|c|c|c|c|c|c|}
\hline \multirow[b]{2}{*}{ Constructs } & \multirow[b]{2}{*}{$\begin{array}{l}\text { Adapted } \\
\text { from }\end{array}$} & \multirow[b]{2}{*}{ Items } & \multicolumn{5}{|c|}{ Factor } \\
\hline & & & $\begin{array}{l}\text { Upbeat } \\
\text { feelings }\end{array}$ & Fear & Disgust & $\begin{array}{l}\text { Brand } \\
\text { Health } \\
\text { Beliefs }\end{array}$ & $\begin{array}{c}\text { Brand } \\
\text { Symbolic } \\
\text { Beliefs } \\
\end{array}$ \\
\hline Upbeat & $\begin{array}{l}\text { Moora- } \\
\text { dian } \\
(1996)\end{array}$ & $\begin{array}{l}\text { Playful } \\
\text { Cheerful } \\
\text { Joyous }\end{array}$ & $\begin{array}{l}.811 \\
.878 \\
.847\end{array}$ & & & & \\
\hline Fear & $\begin{array}{l}\text { Laroche } \\
\text { et al. } \\
(2001)\end{array}$ & $\begin{array}{l}\text { Fearful } \\
\text { Scared } \\
\text { Threatened }\end{array}$ & & $\begin{array}{l}.845 \\
.865 \\
.859\end{array}$ & & & \\
\hline Disgust & $\begin{array}{l}\text { Izard } \\
(1977)\end{array}$ & $\begin{array}{l}\text { Feeling of distate } \\
\text { Disgusted } \\
\text { Feeling of revultion }\end{array}$ & & & $\begin{array}{l}.769 \\
.780 \\
.667\end{array}$ & & \\
\hline $\begin{array}{l}\text { Health } \\
\text { Beliefs }\end{array}$ & $\begin{array}{l}\text { Hemdev } \\
(2005)\end{array}$ & $\begin{array}{l}\text { Danger } \\
\text { Disease } \\
\text { Cancer } \\
\text { Death } \\
\text { Risk }\end{array}$ & & & & $\begin{array}{l}.738 \\
.877 \\
.843 \\
.871 \\
.888\end{array}$ & \\
\hline $\begin{array}{l}\text { Symbolic } \\
\text { Beliefs }\end{array}$ & $\begin{array}{l}\text { Hemdev } \\
(2005)\end{array}$ & $\begin{array}{l}\text { Virility } \\
\text { Independency } \\
\text { Evasion } \\
\text { Freedom } \\
\text { Adventure } \\
\text { Authenticity } \\
\text { Wide-open spaces }\end{array}$ & & & & & $\begin{array}{l}.661 \\
.633 \\
.798 \\
.826 \\
.820 \\
.701 \\
.533\end{array}$ \\
\hline $\begin{array}{l}\text { Mean } \\
\text { S.D. } \\
\text { Reliability }\end{array}$ & & & $\begin{array}{l}1.72 \\
1.14 \\
.85 \\
\end{array}$ & $\begin{array}{c}3.58 \\
1.77 \\
.91 \\
\end{array}$ & $\begin{array}{l}3.96 \\
1.74 \\
.82 \\
\end{array}$ & $\begin{array}{l}5.09 \\
1.59 \\
.84 \\
\end{array}$ & $\begin{array}{l}3.02 \\
1.51 \\
.84 \\
\end{array}$ \\
\hline
\end{tabular}


Table 2. Univariate Results and Post-Hoc Tests

\begin{tabular}{|c|c|c|c|c|c|}
\hline \multicolumn{6}{|c|}{ Univariate Results } \\
\hline $\begin{array}{l}\text { Response } \\
\text { Dimension }\end{array}$ & $\begin{array}{l}\text { ext-only ad } \\
\text { parody } \\
(\mathrm{N}=40) \\
\end{array}$ & $\begin{array}{c}\text { Graphic-only } \\
\text { ad parody } \\
(\mathrm{N}=50) \\
\end{array}$ & $\begin{array}{c}\text { Cigarette } \\
\text { Package } \\
\text { Warning } \\
(\mathrm{N}=49) \\
\end{array}$ & $\mathbf{F}$ & $p$ \\
\hline \multicolumn{6}{|l|}{ Emotional Responses } \\
\hline Fear & 2.72 & 4.06 & 3.80 & 7.54 & .001 \\
\hline Disgust & 2.75 & 4.06 & 4.84 & 20.59 & .000 \\
\hline Upbeat feelings & 2.25 & 1.46 & 1.55 & 6.62 & .002 \\
\hline \multicolumn{6}{|l|}{ Cognitive Responses } \\
\hline Health Beliefs & 4.96 & 5.49 & 4.79 & 2.65 & .074 \\
\hline Symbolic Beliefs & 3.64 & 2.82 & 2.72 & 4.99 & .008 \\
\hline \multicolumn{6}{|c|}{ Post-Hoc Tests } \\
\hline & & & $\begin{array}{l}\text { Text-only } \\
\text { ad parody }\end{array}$ & & $\begin{array}{l}\text { Package } \\
\text { ing }\end{array}$ \\
\hline \multicolumn{6}{|l|}{ Emotional Responses } \\
\hline \multirow[t]{3}{*}{ Graphic-only ad parody } & Fear & & $1.33 * * *$ & \multicolumn{2}{|c|}{.25} \\
\hline & Disgust & & $1.31 * * *$ & \multicolumn{2}{|c|}{$-.77 *$} \\
\hline & \multicolumn{2}{|c|}{ Upbeat feelings } & $-.79 * *$ & \multicolumn{2}{|c|}{-.08} \\
\hline \multicolumn{6}{|l|}{ Cognitive Responses } \\
\hline \multirow[t]{2}{*}{ Graphic-only ad parody } & \multirow{2}{*}{\multicolumn{2}{|c|}{$\begin{array}{l}\text { Health Beliefs } \\
\text { Symbolic Beliefs }\end{array}$}} & $.5^{+}$ & \multicolumn{2}{|c|}{$.70^{*}$} \\
\hline & & & $-.81 *$ & & \\
\hline
\end{tabular}

\section{REFERENCES}

Aloise-Young, Patricia A., John G. Graham and William B. Hansen. 1994. "Peer Influence on Smoking Initiation During Early Adolescence: A Comparison of Group Members and Group Outsiders." Journal of Applied Psychology 79 (2): 281287.

Andrews, J. Craig., Richard G. Netemeyer, Scot Burton, D. Paul Moberg and Ann Christiansen. 2004. "Understanding Adolescent Intentions to Smoke: An Examination of Relationships Among Social Influence, Prior Trial Behavior, and Antitobacco Campaign Advertising." Journal of Marketing 68 (July): 110-123.

Bandura, Albert 1977. Social Learning Theory. New York: General Learning Press.

Bergkvist, Lars and John R. Rossiter. 2007. "The Predictive Validity of Multiple-Item Versus Single-Item Measures of the Same Constructs.” Journal of Marketing Research 44 (May): 175-184.

Berthon, Pierre R., Leyland Pitt and Colin Campbell. 2008. "Ad lib: When Customers Create the Ad." California Management Review 50 (4): 6-30.

Devlin, Elinor, Douglas Eadie, Martine Stead and Kirsty Evans. 2007. "Comparative Study of Young People's Response to Anti-Smoking Messages.” International Journal of Advertising 26 (1): 99-128.

Gallopel-Morvan, Karine, Patrick Gabriel, Marine Le Gall-Ely, Sophie Rieunier and Bertrand Urien. 2011. "The Use of Visual Warnings in Social Marketing: The Case of Tobacco.” Journal of Business Research 64 (1): 7-11. 
Germain, Daniella, Melanie A. Wakefield and Sarah J. Durkin. 2009. “Adolescents' Perceptions of Cigarette Brand Image: Does Plain Packaging Make a Difference.” Journal of Adolescent Health 46 (4): 385-392.

Goodall, Catherine, and Osei Appiah. 2008. “Adolescents' Perception of Canadian Cigarette Package Warning Labels: Investigating the Effects of Message Framing." Health Communication 23 (2): 117-127.

Hammond, David. 2011. "Health Warning Messages on Tobacco Products: A Review." Tobacco Control. doi:10.1136/tc.2010.037630.

Hemdev, Pooja Anil. 2005. "Marlboro - A Mini Case Study.” The Marketing Review 5:73-96.

Hollenbeck, Candice R. and George M. Zinkhan. 2006. "Consumer Activism on the Internet: the Role of Anti-Brand Communities," in Connie Pechmann and Linda Price (Eds.), Advances in Consumer Research, Provo, UT: Association for Consumer Research, 33, 479-485.

Izard, Carroll E. 1977. Human Emotions. New York: Plenum.

Kees, Jeremy, Scot Burton, J. Craig Andrews and John Kozup. 2010. "Understanding How Graphic Pictorial Warnings Work on Cigarette Packaging.” Journal of Public Policy \& Marketing 29 (2): 265-276.

Laroche, Michel, Roy Toffoli, Quihong Zhang and Frank Pons (2001). "A Cross-Cultural Study of the Persuasive Effect of Fear Appeal Messages in Cigarette Advertising: China and Canada." International Journal of Advertising 20 (3): 297-317.

MacKenzie, Scott B, Richard J. Lutz. and George E. Belch. (1986). "The Role of Attitude Toward the Ad as a Mediator of Advertising Effectiveness: A Test of Competing Explanations.” Journal of Marketing Research 23 (May): 130-143.

Maheswaran, Durairaj. 1994. "Country of Origin as a Stereotype: Effects of Consumer Expertise and Attribute Strength on Product Evaluations.” Journal of Consumer Research 21 (2): 354-365.

Mitchell, Andrew A and Jerry C. Olson. 1981. "Are Product a Beliefs the Only Mediator of Advertising Effects on Brand Attitude." Journal of Marketing Research 18 (August): 318-332.

Mooradian, Todd A. 1996. "Personality and Ad-Evoked Feelings: The Case for Extraversion and Neuroticism." Journal of the Academy of Marketing Science 24 (2): 99-109.

Pechmann, Cornelia and Susan J. Knight. 2002. "An Experimental Investigation of the Joint Effects of Advertising and Peers on Adolescents' Beliefs and Intentions about Cigarette Consumption.” Journal of Consumer Research 29 (1): 5-19.

Pechmann, Cornelia and S. Ratneshwar. 1994. "The Effects of Antismoking and Cigarette Advertising on Young Adolescents' Perceptions of Peers Who Smoke.” Journal of Consumer Research 21 (2): 236-251.

Petty, Richard E. and John T. Cacioppo. 1981. Attitudes and Persuasion: Classic and Contemporary Approaches. Dubuque. Iowa: Wm.

Preacher, Kristopher J. and Andrew F. Hayes. 2008. "Asymptotic and Resampling Strategies for Assessing and Comparing Indirect Effects in Multiple Mediator Models.” Behavior Research Methods 40 (3): 879-891.

Rogers, Ronald W. 1975. “A Protection Motivation Theory of Fear Appeals and Attitude Change.” Journal of Psychology 91 (1): 93-114.

Rogers, Ronald W. 1985. “Attitude Change and Information Integration in Fear Appeals.” Psychological Reports 56: 179182.

Rosenstock, Irwin M. 1974. "Historical Origins of the Health Belief Model.” Health Education Monographs 2 (4): 1-8. 
Rumbo, Joseph D. 2002. "Consumer Resistance in a World of Advertising Clutter: The Case of Adbusters." Psychology \& Marketing 19 (2): 127-148.

Sabbane, Lalla Ilhame, François Bellavance and Jean-Charles Chebat. 2009. "Recency Versus Repetition Priming Effects of Cigarette Warnings on Nonsmoking Teenagers: the Moderating Effects of Cigarette Brand Familiarity." Journal of Applied Social Psychology 39 (3): 656-82.

Speck, Paul S. 1991. "The Humorous Message Taxonomy: A Framework for the Study of Humorous Ads." Journal of Current Issues and Research in Advertising 13: 1-44.

Tanner, John F. Jr., James B. Hunt and David R. Eppright. 1991. "The Protection Motivation Model: A Normative Model of Fear Appeals." Journal of Marketing 55 (3): 36-45.

Thompson, Craig J., Aric Rindfleisch and Zeynep Arsel. 2006. "Emotional Branding and the Strategic Value of the Doppelgänger Brand Image.” Journal of Marketing 70 (1): 50-64.

Vanden Bergh, Bruce G., Mira Lee, Elizabeth T. Quilliam and Thomas Hove. 2011. "The Multidimensional Nature and Brand Impact of User-Generated Ad Parodies in Social Media." International Journal of Advertising 30 (1): 103-131.

Zhao, Xinshu, John G. Lynch Jr. and Qimei Chen. 2010. "Reconsidering Baron and Kenny: Myths and Truths about Mediation Analysis." Journal of Consumer Research 37 (August): 197-206. 